\section{Evaluation of Six Nitrogen Fertility Programs on Marketable Yield and Development of Skin Separation in Bell Pepper Fruit}

\author{
Wesley L. Kline ${ }^{1,3,8}$, Christian A. Wyenandt ${ }^{2,4}$, Daniel L. Ward ${ }^{2,5}$, \\ June F. Sudal ${ }^{2,6}$, and Nancy L. Maxwell ${ }^{2,7}$
}

Additional index words. Phytophthora capsici, phytophthora tolerant, Nitamin ${ }^{\circledR}$, silvering

Summary. In this study, the effects of six nitrogen fertility programs and two bell pepper (Capsicum annumm) cultivars were evaluated for marketable yield and incidence of skin separation in fruit. In 2006 and 2007, bell pepper cultivar Aristotle, which is tolerant to the crown rot phase of phytophthora blight (Phytophthora capsici), and a susceptible cultivar, Camelot, were established in a split-plot design with cultivar as the whole-plot factor and fertilizer regime as the subplot factor. Each year, fertility treatments included 1) $180 \mathrm{lb} / \mathrm{acre}$ of soluble nitrogen $(\mathrm{N})$ plus phosphorus $(\mathrm{P})$ and potassium $(\mathrm{K})$ as $20 \mathrm{~N}-8.7 \mathrm{P}-16.6 \mathrm{~K}, 2) 300$ $\mathrm{lb} /$ acre of soluble $\mathrm{N}(4 \mathrm{~N}-0 \mathrm{P}-6.6 \mathrm{~K}), 3) 180 \mathrm{lb} /$ acre of soluble $\mathrm{N}(30 \mathrm{~N}-0 \mathrm{P}-0 \mathrm{~K}), 4)$ $135 \mathrm{lb} /$ acre of soluble $\mathrm{N}(30 \mathrm{~N}-0 \mathrm{P}-0 \mathrm{~K}), 5) 180 \mathrm{lb} /$ acre of granular $\mathrm{N}(43 \mathrm{~N}-0 \mathrm{P}-$ $0 \mathrm{~K})$, and 6$) 135 \mathrm{lb} /$ acre of granular $\mathrm{N}(43 \mathrm{~N}-0 \mathrm{P}-0 \mathrm{~K})$. Soluble fertilizer treatments 1-4 were applied weekly through drip irrigation during the production season. Granular fertility treatments 5 and 6 were applied after bed making but before laying black plastic mulch each year. Additionally, all plots received $180 \mathrm{lb} / \mathrm{acre}$ each of $\mathrm{P}$ and $\mathrm{K}(0 \mathrm{~N}-2.6 \mathrm{P}-4.9 \mathrm{~K})$ plus $2 \mathrm{lb} /$ acre of boron distributed season-long in weekly fertilizer applications. In 2006 and 2007, cultivar had no effect on marketable yield or percent marketable fruit. In 2007, the percentage of harvested fruit with skin separation was significantly higher in fertility programs 1 and 2 compared with program 5. In 2006 and 2007, there were no significant interactions between cultivar and fertility program for marketable yield per plot, fruit with skin separation, percent marketable fruit, or marketable yield per acre. In both years, harvest date has a significant effect on marketable yield per plot, fruit with skin separation, percent marketable fruit, and marketable yield per acre. The percentage of harvested fruit with skin separation was higher in phytophthora-tolerant 'Aristotle' compared with phytophthora-susceptible 'Camelot' in 2006 and 2007. Results of this study suggest that the development of skin separation in bell pepper fruit is more influenced by genotype than $\mathrm{N}$ fertility program.

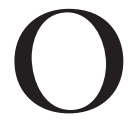
ver 3000 acres of bell pepper are grown annually in New Jersey for fresh market and processing production (Rutgers University, 2005). Bell pepper production in New Jersey represents $5.5 \%$ of the total U.S. production acreage with an estimated value of $\$ 33$ million [U.S. Department of Agriculture (USDA), 2011]. Each year, commercial

${ }^{1}$ Cooperative Extension of Cumberland County, Rutgers New Jersey Agricultural Experiment Station, Extension Education Center, 291 Morton Avenue, Millville, NJ 08332

${ }^{2}$ Rutgers Agricultural Research and Extension Center, Rutgers University, 121 Northville Road, Bridgeton, NJ 08302

${ }^{3}$ Cumberland County Agricultural Agent

${ }^{4}$ Extension Specialist in Vegetable Pathology

${ }^{5}$ Extension Specialist in Pomology

${ }^{6}$ Horticulture Technician

${ }^{7}$ Former Field Researcher IV

${ }^{8}$ Corresponding author. E-mail: wkline@aesop.rutgers. edu. vegetable production recommendations are distributed to vegetable growers in New Jersey and other states in the mid-Atlantic region (Pennsylvania, Delaware, Maryland, and Virginia) to use as a guideline for crop management (Orton, 2011). In recent years, the recommendation for nitrogen fertilization of bell pepper in New Jersey has been to apply $180 \mathrm{lb} / \mathrm{acre}$, with 60 $\mathrm{lb} /$ acre broadcast and incorporated before bed formation followed by an additional $120 \mathrm{lb} /$ acre split evenly through weekly drip irrigation during the production season (Orton, 2011). However, in some instances, bell pepper growers in southern New Jersey have increased fertilizer application rates up to $300 \mathrm{lb}$ of $\mathrm{N}$ per mulch acre because of the very porous, sandy Atlantic coastal plain soils of southern New Jersey.

A methylene urea slow-release polymer-based fertilizer called Nitamin ${ }^{\circledR}$ (Georgia-Pacific Resins, Decatur, GA) in a granular formulation (Nitamin- $43 \mathrm{G}^{\circledR}$ ) or liquid formulation (Nitamin-30L $®$ ) has been developed to supply nitrogen to vegetable crops. The granular formulation consists of $43 \%$ water-soluble $\mathrm{N}$ with $30 \%$ of the $\mathrm{N}$ in the form of methylene urea polymers and $70 \%$ as urea, and the liquid formulation consists of $60 \%$ of the $\mathrm{N}$ as methylene urea polymers and $40 \%$ of the $\mathrm{N}$ as urea. The fertilizer releases nitrogen by microbial decomposition and is completely soluble in water (Reyes et al., 2008). Several case studies have been conducted to determine the effects of the fertilizer on vegetable crop yield. In a Georgia study, marketable yield of bell pepper was as good as or better than that in the standard program when the fertilizer was used in combination with quick-release $\mathrm{N}$ materials, or when the total $\mathrm{N}$ rate was split with Nitamin ${ }^{\circledR}$ applications (Kelley, 2005). In a Texas study, the fertilizer improved tomato yield at lower rates with fewer applications compared with the standard practice resulting in a gross return of $\$ 970-\$ 4563$ per acre (Dainello, 2006). Studies in Delaware determined that the fertilizer applied preplant to corn did not provide superior performance to a split application of urea ammonium nitrate solution (Alley et al., 2006). The use of the fertilizer as a slow-release source of $\mathrm{N}$ in a North Carolina bell pepper production study showed potential use across the state at reduced rates and had a greater impact on yield

\begin{tabular}{llll}
\hline $\begin{array}{l}\text { Units } \\
\begin{array}{l}\text { To convert U.S. to SI, } \\
\text { multiply by }\end{array}\end{array}$ & U.S. unit & SI unit & $\begin{array}{l}\text { To convert SI to U.S., } \\
\text { multiply by }\end{array}$ \\
\hline 0.4047 & acre $(\mathrm{s})$ & $\mathrm{ha}$ & 2.4711 \\
0.3048 & $\mathrm{ft}$ & $\mathrm{m}$ & 3.2808 \\
2.54 & inch(es) & $\mathrm{cm}$ & 0.3937 \\
0.4536 & $\mathrm{lb}$ & $\mathrm{kg}$ & 2.2046 \\
1.1209 & $\mathrm{lb} / \mathrm{acre}$ & $\mathrm{kg} \cdot \mathrm{ha}^{-1}$ & 0.8922 \\
0.0254 & mil & $\mathrm{mm}$ & 39.3701
\end{tabular}


in the coarse-textured soils of the eastern coastal plain region (Reyes et al., 2008).

Phytophthora capsici is a serious pathogen of solanaceous and cucurbit crops in many vegetable production regions of the United States (Ristaino and Johnston, 1999). The crown rot phase of phytophthora blight can cause substantial economic losses on some farms in New Jersey each year. Since $P$. capsici can be found on most vegetable farms in the southern region of the state, many bell pepper growers in New Jersey plant phytophthora-tolerant cultivars. Some commonly grown bell pepper cultivars in New Jersey include phytophthoratolerant cultivars, Aristotle and Paladin, as well as phytophthora-susceptible cultivars Camelot and Alliance (Rutgers University, 2005). Additionally, bell pepper fields in this region are often rotated with cucurbit crops such as summer squash (Cucurbita pepo) or cucumber (Cucumis sativus) or solanaceous crops such as eggplant (Solanum melongena) or tomato (Solanum lycopersicum), which also are susceptible to the pathogen. Because of poor crop rotations and the repeated use of the fungicide, mefenoxam, insensitive strains of $P$. capsici have developed on some vegetable farms in southern New Jersey (Fogg and Johnston, 2003; Parra and Ristaino, 2001). Since the early 1990s, researchers in the state have cooperated with commercial breeders and seed companies to evaluate bell pepper breeding lines and cultivars under field conditions in southern New Jersey to identify those breeding lines or cultivars which exhibit field tolerance to local isolates of $P$. capsici. Results of these studies have led many vegetable growers in southern New Jersey to plant phytophthora-tolerant bell pepper cultivars over the past decade.

Importantly, observations made during these research evaluations over the past decade have determined that some cultivars or breeding lines with resistance or tolerance to the crown rot phase of phytophthora blight have exhibited what is now referred to as skin separation, or "silvering," of bell pepper fruit (Fig. 1). Although only cosmetic in nature, skin separation is a disorder that reduces aesthetic fruit quality in bell pepper. Skin separation has been generically defined as a "silvery white discoloration," which

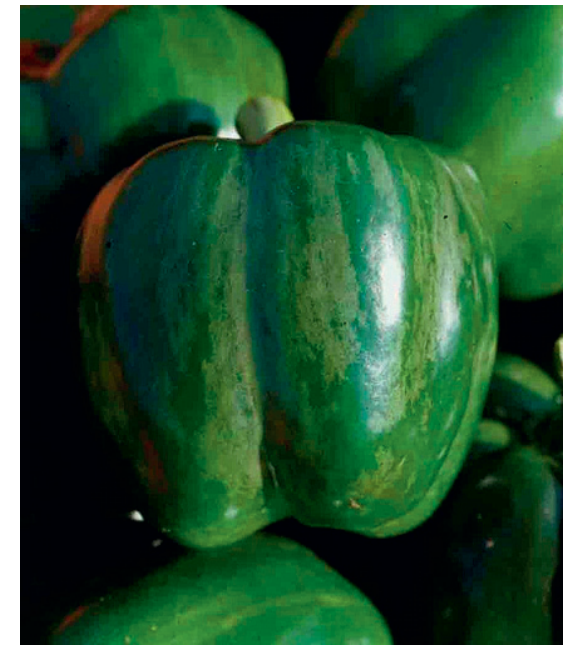

Fig. 1. Skin separation or "silvering" on fruit of mature bell pepper.

appears as "diffused or solid silvery white areas" on fruit. Because it is considered a "defect" by USDA grading standards, skin separation could potentially be used to reduce the grade of fruit (USDA, 2005). Because resistant and/or tolerant cultivars make up as much as $30 \%-40 \%$ of the bell pepper acreage in southern New Jersey, many growers are at a potential risk for reduced fruit quality and grade rejection due to the presence of skin separation (Rutgers University, 2005). In some years in New Jersey, incidence of skin separation has been estimated to be as high as $66 \%$ on some harvest dates in some phytophthora-tolerant cultivars and breeding lines (Wyenandt and Kline, 2006 b). Preliminary research on the possible relationship between phytophthora resistance and the development of skin separation suggests that environmental factors and cultural practices may also influence the amount of skin separation development in bell pepper fruit (Wyenandt and Kline, 2006a; Wyenandt et al., 2007). Additionally, given the increasing costs of crop production (e.g., fertilizer costs) in the United States, bell pepper growers need to know if recommended $\mathrm{N}$ rates and/or newly developed nitrogen additives will be cost effective and have any influence on the development of skin separation in bell pepper fruit.

The objectives of this research were to determine the effects of six nitrogen fertility programs and two commercial bell pepper cultivars with or without tolerance to the crown rot phase of phytophthora blight on marketable yield and incidence of skin separation in fruit of bell pepper.

\section{Materials and methods}

In 2006 and 2007, experiments were established in a split-plot design with cultivar as the whole-plot factor and fertilizer regime as the subplot factor with six replications. These experiments were conducted in separate fields (Aura sandy loams) at the Rutgers Agricultural Research and Extension Center (RAREC) in Bridgeton, NJ. On 13 June 2006 and 21 May 2007, phytophthora-tolerant 'Aristotle' (Seminis Seeds, Oxnard, CA) and phytophthora-susceptible 'Camelot' (Stokes Seed, Vineland, NJ) obtained from a local seedling producer were transplanted by hand (18 inches apart in-row) into double rows (16 inches between rows) on black plastic mulch (1.25-mm thick) beds (a total of 20 plants per plot) spaced on 5 -ft centers with drip irrigation. In both years, all treatment plots were 16.5 -ft long with guard rows of 'Corcel' hot pepper (Seminis Seeds) planted in the two outside rows of the experimental plot area and at the end of each row.

Each year, $\mathrm{N}$ fertility programs were 1) $180 \mathrm{lb} /$ acre of $\mathrm{N}(20 \mathrm{~N}-$ 8.7P-16.6K; Scotts-Sierra Horticultural Products, Marysville, $\mathrm{OH}), 2$ ) $300 \mathrm{lb} / \mathrm{acre}$ of $\mathrm{N}$ (4N-0P-6.6K; United Agri Products, Malaga, NJ), 3) Nitamin-30L® at $180 \mathrm{lb} /$ acre of $\mathrm{N}(30 \mathrm{~N}-0 \mathrm{P}-0 \mathrm{~K}), 4)$ Nitamin-30L $\AA$ at $135 \mathrm{lb} /$ acre of $\mathrm{N}(30 \mathrm{~N}-0 \mathrm{P}-0 \mathrm{~K})$, $5)$ Nitamin-43G ${ }^{\circledR} 180 \mathrm{lb} /$ acre of $\mathrm{N}(43 \mathrm{~N}-0 \mathrm{P}-0 \mathrm{~K})$, and 6) Nitamin$43 \mathrm{G}^{\circledR} 135 \mathrm{lb} /$ acre of $\mathrm{N}(43 \mathrm{~N}-0 \mathrm{P}-$ $0 \mathrm{~K})$. Soluble fertilization treatments 1-4 began on 21 June 2006 and 31 May 2007 and continued weekly (every $7 \mathrm{~d})$ through the drip irrigation for a total of 12 or 15 applications each year. Each year, granular fertility treatments 5 and 6 were applied after bed formation, but before laying the black plastic mulch, in two bands per bed, 2 inches from each side of the centered drip tape. Additionally, in each year, all plots received $180 \mathrm{lb} /$ acre of $\mathrm{P}$ and $\mathrm{K}(\mathrm{ON}-$ 2.6P-4.9K; Oakland Farms, Bridgeton, $\mathrm{NJ}$ ) and $2 \mathrm{lb} /$ acre of boron (Solubor; U.S. Borax, Forrest City, AR) distributed evenly in weekly N fertility applications during the production season. In each year, all insecticide and fungicide applications for insect and disease control were done according to local 
standard practices in southern New Jersey (Orton, 2011).

All mature green pepper fruit from each treatment were harvested on 2 and 15 Aug., 6 and 18 Sept., and 5 and 23 Oct. in 2006 and on 12 and 26 July, 13 and 29 Aug., 12 Sept., and 2 and 31 Oct. in 2007. At each harvest, all fruit were graded and sorted by weight where extra large fruit were $\geq 0.50 \mathrm{lb}$, large fruit were 0.33 $0.49 \mathrm{lb}$, medium fruit were $0.25-0.32$ $\mathrm{lb}$, and fruit $\leq 0.24 \mathrm{lb}$ were culled out. Weights of extra large, large, and medium fruit were combined to determine marketable yield in pounds per plot and total marketable yield (pounds per acre). Additionally at each harvest, all fruit were evaluated for the presence of skin separation, or "silvering," by visually examining each fruit (Fig. 1). Fruit with any visible appearance of skin separation was scored as positive, regardless of its severity (i.e., the total percentage of fruit surface with "silvering" present on the surface). The percentage of marketable fruit with skin separation was determined by dividing the total number of marketable fruit (i.e., extra large, large, and medium) with skin separation by the total number of marketable fruit with and without skin separation. For this study, fruit with skin separation were still considered marketable and included in total marketable yield. In 2006, because of the death of a few plants in some treatment plots, marketable yield (pounds per plot) were corrected to approximate yield from 20 total plants per plot. Total rainfall at RAREC for the months of June, July, August, and September was $7.39,5.7,2.46$, and 3.88 inches, respectively, in 2006 and was 2.34, $2.02,3.13$, and 0.53 inches, respectively, in 2007.

Statistical Analysis. To test for main effects and interactions of cultivar, fertilization regime, and harvest date, a mixed-effects repeated measures analysis of variance (ANOVA) was fit to the data using the MIXED procedure of SAS (version 9.1; SAS Institute, Cary, NC). For marketable yield per year, there were no repeated measurements so a mixed-effects ANOVA for a split plot was used, otherwise the analyses were alike. The comparison of fertilization main effect means was performed using Tukey's honestly significant difference test. Significant interaction effects were further analyzed using the SLICE option of the MIXED procedure to perform tests of simple main effects within each date of harvest. Departure from the distributional assumptions for the model was assessed using Q-Q plots and plots of standardized residuals.

\section{Results and discussion}

EFFECT ON MARKETABLE YIELD. In both years, there were no significant differences in marketable yield or in the percentage of marketable fruit among the fertility programs, suggesting that there was no added benefit in increased marketable yield at the higher fertility rates applied in granular form before transplanting or in weekly applications during the production season (Table 1). Marketable yield in Nitamin ${ }^{\circledR}$ treatments applied either in granular or liquid form were comparable to the standard fertilizer treatment at the low or

Table 1. Effects of six nitrogen fertility programs on marketable yield per plot, percentage of marketable fruit with skin separation (i.e., silvering), total percentage of marketable fruit harvested, and total marketable yield of two bell pepper cultivars in southern New Jersey in 2006 and 2007.

\begin{tabular}{|c|c|c|c|c|c|c|c|c|}
\hline \multirow[b]{2}{*}{ Fertility programv } & \multicolumn{2}{|c|}{$\begin{array}{c}\text { Marketable } \\
\text { yield } \\
(\mathrm{lb} / \text { plot })^{\mathrm{z}}\end{array}$} & \multicolumn{2}{|c|}{$\begin{array}{l}\text { Marketable } \\
\text { fruit with skin } \\
\text { separation }(\%)^{y}\end{array}$} & \multicolumn{2}{|c|}{$\begin{array}{c}\text { Marketable } \\
\text { fruit }(\%)^{x}\end{array}$} & \multicolumn{2}{|c|}{$\begin{array}{c}\text { Total marketable } \\
\text { yield } \\
(1 \mathrm{~b} / \mathrm{acre})^{\mathrm{w}}\end{array}$} \\
\hline & 2006 & 2007 & 2006 & 2007 & 2006 & 2007 & 2006 & 2007 \\
\hline 1) Soluble N $180 \mathrm{lb} /$ acre $(20 \mathrm{~N}-8.7 \mathrm{P}-16.6 \mathrm{~K})$ & 9.7 & 22.8 & 9.2 & $23.4 \mathrm{a}^{\mathrm{u}}$ & 71.6 & 81.2 & 27,036 & 84,572 \\
\hline 2) Soluble N $300 \mathrm{lb} /$ acre $(4 \mathrm{~N}-0 \mathrm{P}-6.6 \mathrm{~K})$ & 11.1 & 23.2 & 12.5 & $23.5 \mathrm{a}$ & 75.6 & 82.9 & 32,277 & 85,681 \\
\hline 3) Soluble N $180 \mathrm{lb} /$ acre $(30 \mathrm{~N}-0 \mathrm{P}-0 \mathrm{~K})$ & 9.8 & 22.5 & 10.5 & $21.4 \mathrm{ab}$ & 74.9 & 78.6 & 28,546 & 82,987 \\
\hline 4) Soluble N $135 \mathrm{lb} /$ acre $(30 \mathrm{~N}-0 \mathrm{P}-0 \mathrm{~K})$ & 10.2 & 21.6 & 11.2 & $19.6 \mathrm{ab}$ & 73.4 & 78.0 & 29,397 & 79,761 \\
\hline 5) Granular N $180 \mathrm{lb} /$ acre $(43 \mathrm{~N}-0 \mathrm{P}-0 \mathrm{~K})$ & 10.4 & 21.2 & 13.0 & $18.5 \mathrm{~b}$ & 71.9 & 78.2 & 26,916 & 78,710 \\
\hline 6) Granular N $135 \mathrm{lb} /$ acre $(43 \mathrm{~N}-0 \mathrm{P}-0 \mathrm{~K})$ & 10.0 & 21.8 & 8.9 & $20.7 \mathrm{ab}$ & 76.4 & 77.8 & 28,557 & 80,612 \\
\hline Source & 2006 & 2007 & 2006 & 2007 & 2006 & 2007 & 2006 & 2007 \\
\hline 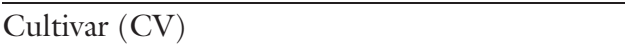 & 0.505 & 0.506 & 0.004 & $<0.0001$ & 0.095 & 0.101 & 0.072 & 0.388 \\
\hline Fertility program (FP) & 0.88 & 0.427 & 0.131 & 0.009 & 0.705 & 0.162 & 0.8 & 0.305 \\
\hline $\mathrm{CV} \times \mathrm{FP}$ & 0.709 & 0.261 & 0.291 & 0.384 & 0.815 & 0.206 & 0.912 & 0.16 \\
\hline Harvest date (HD) & $<0.0001$ & $<0.0001$ & $<0.0001$ & $<0.0001$ & $<0.0001$ & $<0.0001$ & - & - \\
\hline $\mathrm{HD} \times \mathrm{CV}$ & 0.002 & $<0.0001$ & $<0.0001$ & $<0.0001$ & 0.501 & 0.134 & - & - \\
\hline $\mathrm{HD} \times \mathrm{FP}$ & 0.884 & 0.932 & 0.414 & 0.322 & 0.756 & 0.706 & - & - \\
\hline $\mathrm{HD} \times \mathrm{CV} \times \mathrm{FP}$ & 0.927 & 0.852 & 0.261 & 0.694 & 0.996 & 0.69 & - & - \\
\hline
\end{tabular}

${ }^{\mathrm{z}}$ Marketable yield as a total combined weight of medium $(0.25-0.32 \mathrm{lb})$, large $(0.33-0.49 \mathrm{lb})$, and extra large $(\geq 0.50 \mathrm{lb})$ fruit per 16.5 - $\mathrm{ft}$ plot $(5.03 \mathrm{~m})$ in 2006 and $2007 ; 1 \mathrm{lb}=$ $0.4536 \mathrm{~kg}$.

yPercentage of total marketable fruit (medium + large + extra large) per 16.5-ft plot with skin separation in 2006 and 2007

xPercentage of total harvested fruit that were of marketable size (medium + large + extra large) per 16.5-ft plot in 2006 and 2007

wTotal marketable yield (medium + large + extra large) in 2006 and 2007.

$\left.{ }^{v} \mathrm{l}\right) 180 \mathrm{lb} /$ acre nitrogen $(\mathrm{N})$ plus phosphorus $(\mathrm{P})$ and potassium $(\mathrm{K})$ as $20 \mathrm{~N}-8.7 \mathrm{P}-16.6 \mathrm{~K}$ (Scotts-Sierra Horticultural Products, Marysville, OH); 2 ) $300 \mathrm{lb} /$ acre N (4N-0P-

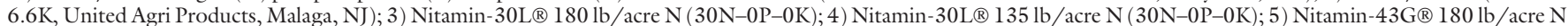
$(43 \mathrm{~N}-0 \mathrm{P}-0 \mathrm{~K})$; and 6) Nitamin-43G ${ }^{\circledR} 135 \mathrm{lb} /$ acre N (43N-0P-0K). Fertilization treatments $1-4$ began on 21 June 2006 and 31 May 2007 and continued weekly for a total of 12 or 15 applications each year, respectively. Granular fertility treatments 4 and 5 were applied after bed making, but before laying plastic mulch, in two bands per bed, 2 inches $(5.1 \mathrm{~cm})$ from the drip tape. Additionally, all plots received $180 \mathrm{lb} /$ acre of $\mathrm{P}$ and $\mathrm{K}(0 \mathrm{~N}-2.6 \mathrm{P}-4.9 \mathrm{~K})$ season-long spread out in weekly applications along with $2 \mathrm{lb} / \mathrm{acre}$ boron; $1 \mathrm{lb} / \mathrm{acre}=1.1209 \mathrm{~kg} \cdot \mathrm{ha}^{-1}$.

"Means within a column followed by the same letter are not significantly different according to Tukey's honestly significant difference test at $P=0.05 ;(-)=$ not applicable. 
high $\mathrm{N}$ rate (Table 1 ). In 2006, total marketable yield per acre among fertility programs ranged from $\approx 27,000$ to $32,000 \mathrm{lb}$. In 2007, marketable yields ranged from $\approx 79,000$ to $85,000 \mathrm{lb} /$ acre and were nearly two and a half times that in 2006. The large variability in marketable yield between years is likely due to the $\approx 3$-week difference in planting date. In 2007, transplants were set on 21 May compared with 13 June in 2006. The lower yields in 2006 were consistent with yields of late bell pepper plantings in commercial fields in southern New Jersey.

In both years, there was a significant harvest date $\times$ cultivar interaction for marketable yield. The interaction was not consistent between years (Figs. 2 and 3). In 2006, 'Camelot' yielded more than 'Aristotle' in midseason $(P=0.0021)$ but less at the end of the season $(P=0.0299)$ (Fig. 2). In 2006, when transplants were set at a later date, higher midseason yields occurred with 'Camelot' after which 'Aristotle' yields were similar to, then finally surpassed those of 'Camelot' (Fig. 2). In contrast, in 2007, 'Camelot' yielded less than 'Aristotle' at the first harvest $(P<0.001)$ and more at the last harvest $(P<0.001)$ (Fig. 3). The yield profile in 2007 indicates that although total marketable yields were similar for the two cultivars during much of the production season, yield for 'Camelot' was higher than 'Aristotle' at the last harvest date (Fig. 3).

EFFECT OF FERTILITY PROGRAM ON PERCENTAGE OF HARVESTED FRUIT WITH SKIN SEPARATION. In 2006, fertility program had no effect on the percentage of harvested fruit with skin separation $(P=0.131)$ (Table 1$)$. The percentage of fruit with skin separation for the combined cultivars ranged from $8.9 \%$ to $13.0 \%$ in 2006 (Table 1). In 2007 , fertility program had a significant effect on the percentage of harvested fruit with skin separation $(P=0.009)$. In 2007 , the percentage of harvested fruit with skin separation ranged from $18.5 \%$ to $23.5 \%$ depending on fertility program (Table 1 ). The percentage of harvested fruit with skin separation in fertility programs with soluble $\mathrm{N} 180$ $\mathrm{lb} /$ acre $[20 \mathrm{~N}-8.7 \mathrm{~K}-16.6 \mathrm{~K}$ (fertility program 1)] and soluble $\mathrm{N} 300 \mathrm{lb} /$ acre $[4 \mathrm{~N}-0 \mathrm{P}-6.6 \mathrm{~K}$ (fertility program $2)$ ] was significantly higher than the granular N $180 \mathrm{lb} /$ acre [43N-0P-0K (fertility program 5)] in 2007. There was no significant cultivar $\times$ fertility

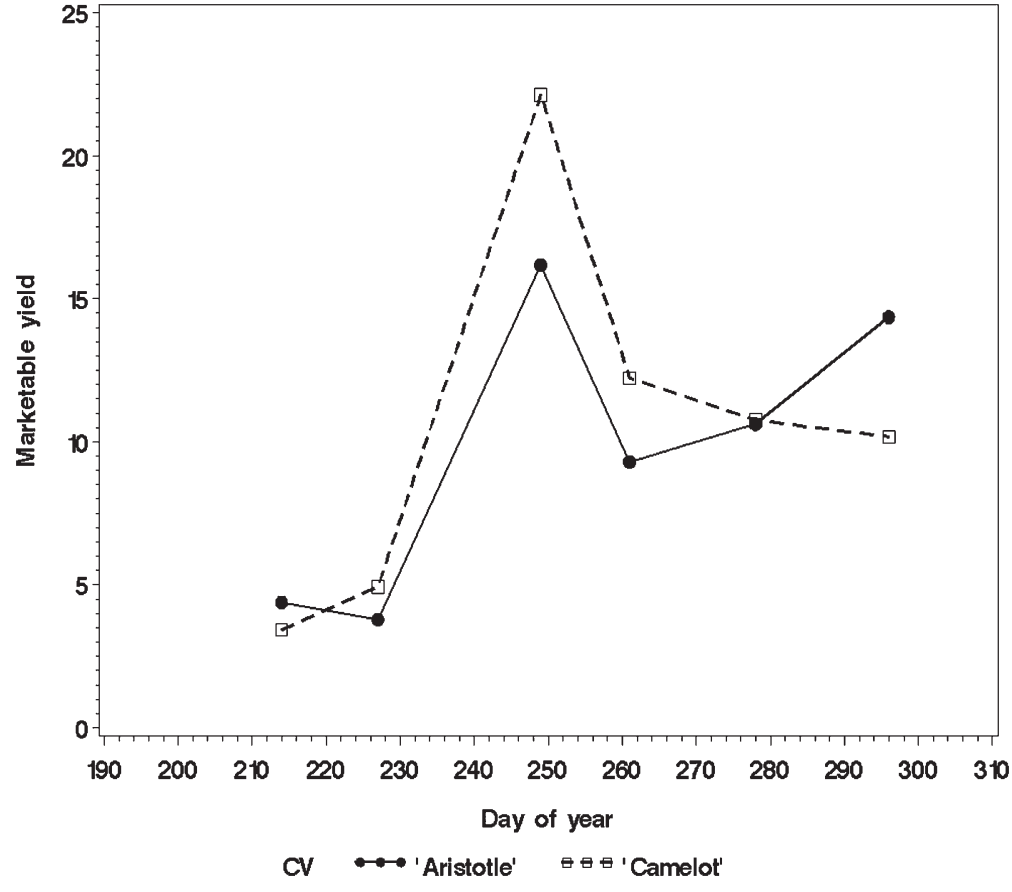

Fig. 2. Interaction between bell pepper cultivar and harvest date on marketable yield [medium (0.25-0.32 lb), large (0.33-0.49 lb), and extra large $(\geq 0.50 \mathrm{lb})$ fruit] per $16.5-\mathrm{ft}(5.03 \mathrm{~m})$ plot of phytophthora-tolerant 'Aristotle' (solid line) and phytophthora-susceptible 'Camelot' (dashed line) at southern New Jersey in 2006; $1 \mathrm{lb}=0.4536 \mathrm{~kg}$.

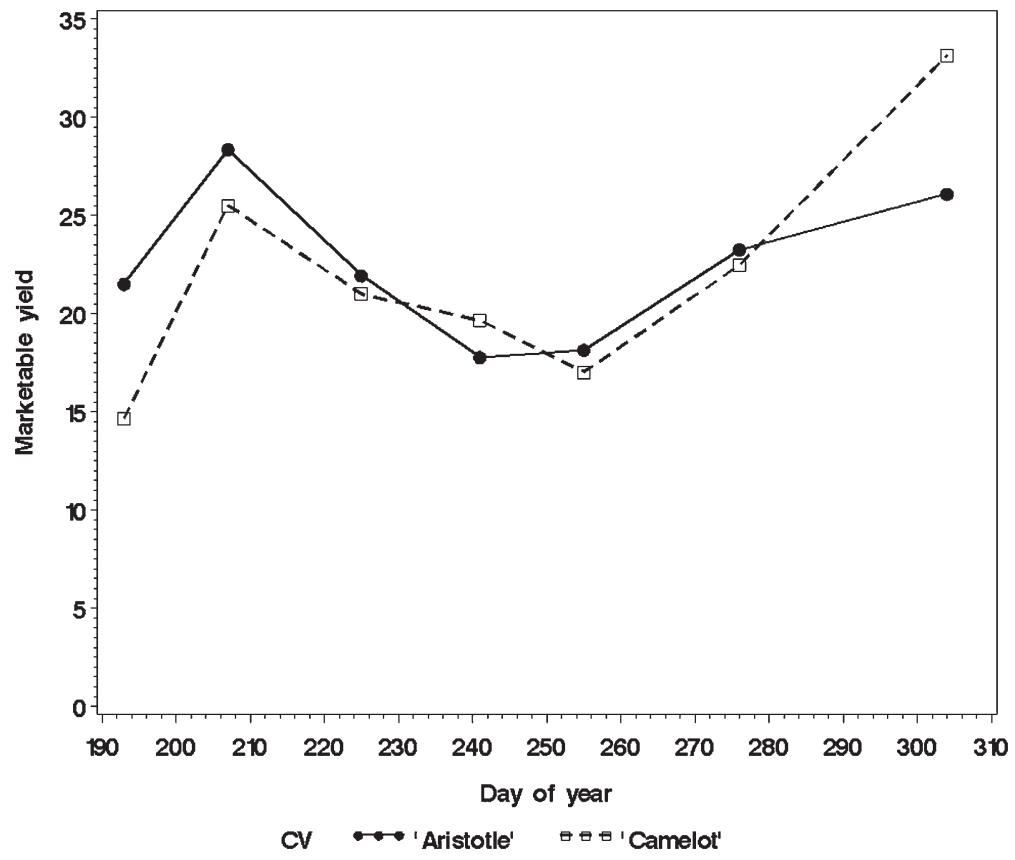

Fig. 3. Interaction between bell pepper cultivar and harvest date on marketable yield [medium (0.25-0.32 lb), large $(0.33-0.49 \mathrm{lb})$, and extra large $(\geq 0.50 \mathrm{lb})$ fruit] per $16.5-\mathrm{ft}(5.03 \mathrm{~m})$ plot of phytophthora-tolerant 'Aristotle' (solid line) and phytophthora-susceptible 'Camelot' (dashed line) at southern New Jersey in 2007; $1 \mathrm{lb}=0.4536 \mathrm{~kg}$.

program, harvest date $\times$ fertility program, or harvest date $\times$ cultivar $\times$ fertility program interactions in both years of the study (Table 1 ).
EfFect of Cultivar ON THE DEVELOPMENT OF SKIN SEPARATION IN BELL PEPPER FRUIT. In both years, there was a significant cultivar $\times$ harvest 
date interaction (Table 1). The percentage of harvested fruit with skin separation was higher in 'Aristotle' when compared with 'Camelot' (Figs. 4 and 5). In 2006, the percentage of harvested fruit with skin separation in 'Aristotle' increased during the production season (Fig. 4). In contrast, the number of harvested fruit with skin separation in 'Camelot' remained consistently low $(<5 \%)$ during the entire production season (Fig. 4).

In 2007, the percentage of fruit with skin separation varied between cultivars at each harvest (Fig. 5). Unlike 2006, the percentage of harvested fruit with skin separation at each harvest in 2007 increased in both cultivars toward the middle of the production season, and then decreased at later harvest dates (Fig. 5 ). At all harvest dates, the percentage of harvested fruit with skin separation was higher in 'Aristotle' when compared with 'Camelot' (Fig. 5). These data are consistent with our hypothesis that the development of skin separation, or "silvering," in bell pepper cultivars is more strongly influenced by genetics than environment or cultural practices and may be linked to phytophthora resistance. The percentages of fruit with skin separation varied by harvest date and cultivar during this study and are similar to other results (Wyenandt and Kline, 2006a, 2006b; Wyenandt et al., 2007).

\section{Conclusions}

In this study, six $\mathrm{N}$ fertility programs were evaluated for their effects on marketable yield and the development of fruit skin separation, or "silvering," using a phytophthora-tolerant and a phytophthora-susceptible bell pepper cultivar. In both years, there were no significant differences in marketable yield or percentage of marketable fruit suggesting that Nitamin ${ }^{\circledR}$ applied as an at-planting granular application or weekly through the drip system was comparable to two standard fertility programs used by bell pepper producers in New Jersey. Importantly, there were no significant differences in marketable yield between the low and high application fertility rates in both years, suggesting that excessive fertility practices (i.e., more than the current recommended rates) currently being used by bell pepper growers in New Jersey are

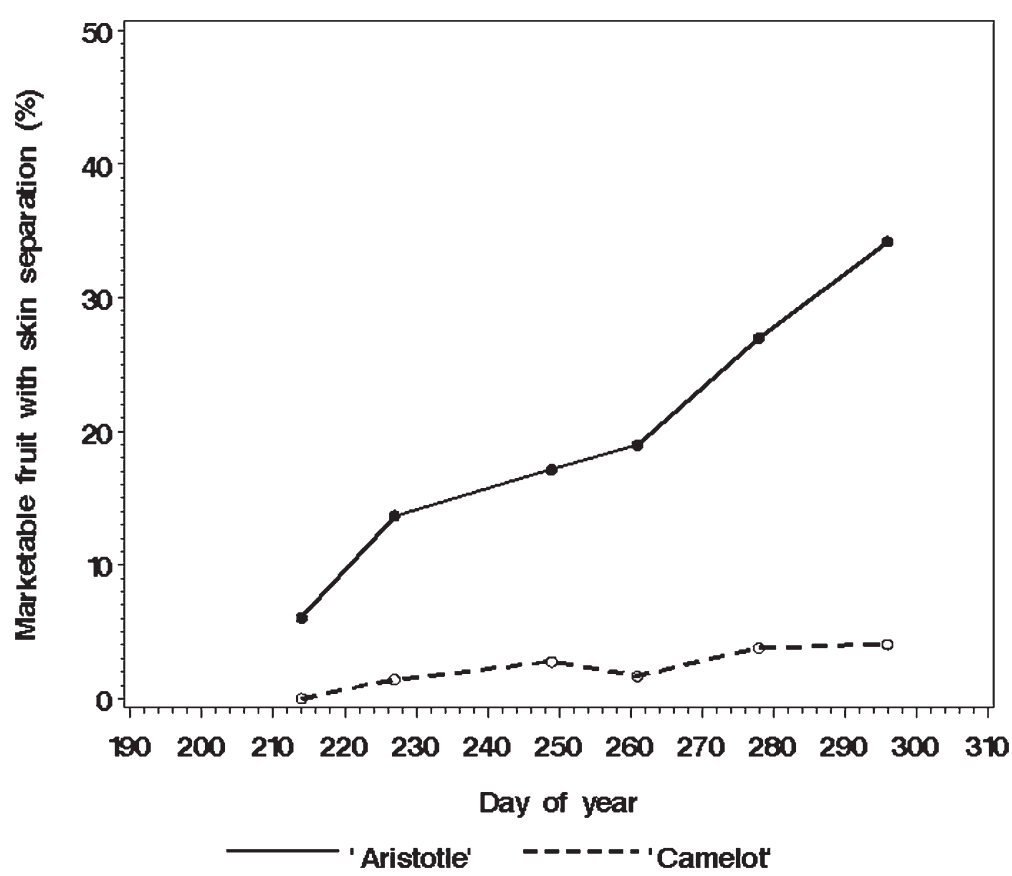

Fig. 4. Percentage of marketable bell pepper fruit [medium $(0.25-0.32 \mathrm{lb})$, large $(0.33-0.49 \mathrm{lb})$, and extra large $(\geq 0.50 \mathrm{lb})$ fruit] per $16.5-\mathrm{ft}(5.03 \mathrm{~m})$ plot with skin separation or "silvering" in phytophthora-tolerant 'Aristotle' (solid line) and phytophthora-susceptible 'Camelot' (dashed line) at each harvest date at southern New Jersey in $2006 ; 1 \mathrm{lb}=0.4536 \mathrm{~kg}$.

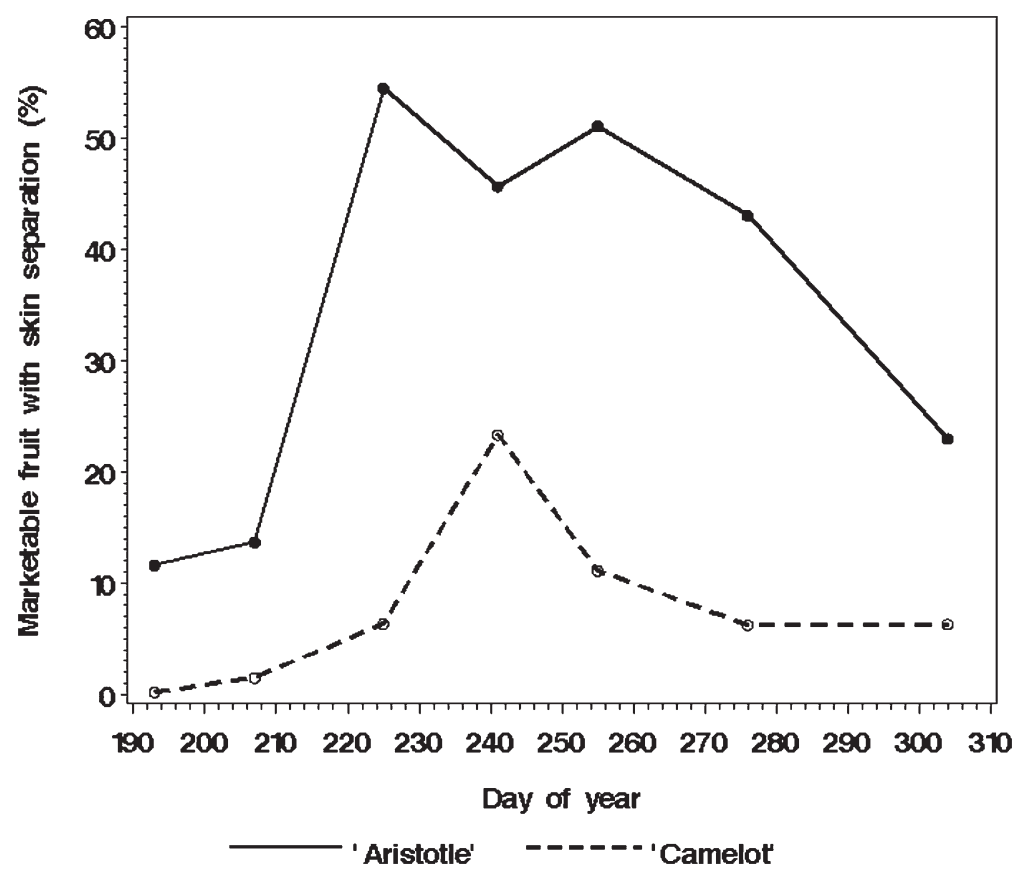

Fig. 5. Percentage of marketable bell pepper fruit [medium $(0.25-0.32 \mathrm{lb})$, large $(0.33-0.49 \mathrm{lb})$, and extra large $(\geq 0.50 \mathrm{lb})$ fruit] per $16.5-\mathrm{ft}(5.03 \mathrm{~m})$ plot with skin separation or "silvering" in phytophthora-tolerant 'Aristotle' (solid line) and phytophthora-susceptible 'Camelot' (dashed line) at each harvest date at southern New Jersey in $2007 ; 1 \mathrm{lb}=0.4536 \mathrm{~kg}$.

unwarranted. Cultivar had more influence on the development of skin separation in bell pepper fruit than fertility program. In this study, phytophthora-tolerant 'Aristotle' was more susceptible to skin separation than the phytophthora-susceptible 'Camelot', suggesting that resistance 
and/or tolerance to the crown rot phase of phytophthora blight and the development of skin separation in bell pepper fruit may be associated. There are at least 13 or 14 known physiological races of $P$. capsici (Glosier et al., 2008; Sy et al., 2008). In 2008, Monroy-Barbosa and Bosland confirmed the existence of race-specific resistance to $P$. capsici using recombinant inbred lines and also showed that the resistance genes are at different loci. MonroyBarbosa and Bosland (2008) also suggested that a linkage between some $P$. capsici resistance genes may exist. More research needs to be conducted on the molecular genetics, which lead to the development of skin separation in bell pepper fruit, and on its relationship with phytophthora resistance and/or tolerance in bell pepper cultivars. Additionally, the effects of environmental factors and/or cultural practices, such as soil and air temperature fluctuations and irrigation schedule (i.e., soil moisture levels), on the development of skin separation in bell pepper fruit needs to be examined. Research at local and regional levels evaluating different production systems and cultural practices and the use of cultivars with or without resistance or tolerance to the crown rot phase of phytophthora blight should help extension personnel and crop consultants make recommendations to bell pepper producers to help reduce the potential for the development of skin separation in fruit.

\section{Literature cited}

Alley, M., G. Binford, S. Phillips, and D. Osmond. 2006. Agricultural management of enhanced efficiency fertilizers: Eastern coastal states. Proc. Amer. Soc. Agron., Crop Sci. Soc. Amer., Soil Sci. Soc. Amer. Abstr. 97.

Dainello, F.J. 2006. Nitamin fertilizer increases marketable yield and crop quality in tomato studies. Texas Coop. Ext. Veg. Production Mktg. News 16:1-2.

Fogg, M.L. and S.A. Johnston. 2003. Mefenoxam sensitivity of Phytophthora capsici isolates in New Jersey. Phytopathology 93:S26 (abstr.).

Glosier, B.R., E.A. Ogundiwin, G.S. Sidhu, D.R. Sischo, and J.P. Prince. 2008. A differential series of pepper (Capsicum annuиm) lines delineates fourteen physiological races of Phytophthora capsici. Euphytica 162:23-30.

Kelley, W.T. 2005. Additional research on the use of Nitamin in bell pepper production, p. 23-25. In: W.T. Kelley and D.B. Langston (eds.). Georgia vegetable extension research report 2005. Univ. Georgia Coop. Res. Ext. Publ. 5-2006.

Monroy-Barbosa, A. and P.W. Bosland. 2008. Genetic analysis of phytophthora root rot race-specific resistance in chili pepper. J. Amer. Soc. Hort. Sci. 133: $825-829$.

Orton, T.J.(ed.). 2011. Commercial Vegetable Production Recommendations. Rutgers Coop. Ext. Publ. E001.19 Mar. 2011. <http://www.njveg.rutgers.edu/ html/gc-2production-guide.html>.

Parra, G. and J.B. Ristaino. 2001. Resistance to mefenoxam and metalaxyl among field isolates of Phytophthora capsici causing phytophthora blight of bell pepper. Plant Dis. 85:1069-1075.

Reyes, L.M., D.C. Sanders, and W.G. Buhler. 2008. Evaluation of slow-release fertilizers on bell pepper. HortTechnology 18:393-396.

Ristaino, J.B. and S.A. Johnston. 1999. Ecologically-based approaches to management of phytophthora blight in bell pepper. Plant Dis. 83:1080-1089.

Rutgers University. 2005. Crop Profile for Bell Peppers in New Jersey. 19 Mar. 2009. <http://www.pestmanagement. rutgers.edu/NJinPAS/CropProfiles / NJPpeppercp05.pdf>.

Sy, O., R. Steiner, and P.W. Bosland. 2008. Recombinant inbred line differential identifies race-specific resistance to phytophthora root rot in Capsicum annuum. Phytopathology 98:867-870.

U.S. Department of Agriculture. 2005. United States Standards for Grades of Sweet Peppers. 23 Mar. 2011. <http://www.ams. usda.gov/AMSv1.0/getfile?dDocName= STELPRDC5050318>.

U.S. Department of Agriculture. 2011. Vegetables Summary 2011. 23 Mar. 2011 . <http://usda.mannlib.cornell. edu/usda/current/VegeSumm/VegeSumm01-27-2011.pdf $>$.

Wyenandt, A. and W.L. Kline. 2006a. Effects of cultivar and production system on the development of skin separation (silvering) in bell pepper fruit in New Jersey. Phytopathology 96:S125 (abstr.).

Wyenandt, C.A. and W.L. Kline. 2006b. Evaluation of skin separation (silvering) in fruit of bell pepper cultivars. HortScience 41:494 (abstr.).

Wyenandt, C.A., W.L. Kline, D.L. Ward, J.F. Sudal, and N.L. Maxwell. 2007. Relationship between skin separation and phytophthora-resistance in bell pepper cultivars and breeding lines. Phytopathology 97:S125 (abstr.). 